\title{
Quality Improvement of Corn Husk as Raw Material for Textile Products
}

\author{
Hasdiana, Ayuddin \\ Department of Visual Arts Education \\ Department of Civill Engineer \\ Universitas Negeri Gorontalo \\ Gorontalo, Indonesia \\ diana_8224@yahoo.co.id
}

\begin{abstract}
Corn is a prominent commodity in Gorontalo, Indonesia. Its productivity in Gorontalo continues to increase. While the focus in corn production is the kernel, the husk is considered as a waste. In this research, corn husk was processed in order to meet the quality standard of raw materials used in making textile products. This research used experimental method and was conducted in 2 stages: identification of the husk characteristics through natural observation and examination of its chemical structure; and the processing of the husk including coloring, sorting, weaving, and forming. The results showed that the best corn husk to be used as raw material for textile products was the middle layer husk because it is clean, medium-sized, palecolored, thick but flexible. After processes, indicated that its strength increased and its color changed brighter. The processed husk was able to be woven properly and used as raw material for textile products.
\end{abstract}

Keywords—corn husk; raw material; textile products

\section{INTRODUCTION}

Indonesia with its huge natural resources has various types of carbohydrate food namely rice, cassava, sago and corn (maize). Corn (maize) that is one of the superior products in Gorontalo can be made as the processed foods. Unfortunately, during this time the processing of corn (maize) is focused on the seed while the other components from the corn (maize) such as the corn leaf, corncob, cornstalk, and cornhusk only become the waste.

The corn kernels used as food represent only $5 \%$ of food crops while $95 \%$ of the rest of corn plants become the natural waste such as cornstalk, corn leaf, cornhusk, and corncob[1].

Corn (maize) is Gorontalo superior commodity because this is the special commodity that can be found in every subs district, regency/city - almost $53.73 \%$ of corn (maize) in every subs district in Gorontalo [2]. The presented data indicates the corn (maize) has been able to create the beneficial impact on the improvement of the economic sector of society and the significant regional income.

This research explores the corn waste especially cornhusk which will be processed as the raw material for the textile product that has not been improved significantly.

Sponsored by DRPM Kemristekdikti through LPPM State University of Gorontalo.
The processing of cornhusk is an attempt at giving the significant contribution to utilize the cornhusk and meeting the need of textile fiber to produce the textile products containing local values.

It is hoped that the quality of cornhusk as the raw material of textile products can be improved by the efficient technology for processing cornhusk in order Gorontalo - the producer of corn (maize) - can optimize its waste treatment and the tradability of cornhusk, increase the quality of community life in Gorontalo, and answer the problem about the waste of cornhusk.

\section{LITERATURE REVIEW}

\section{A. Study on Corn Crops}

In addition to wheat and rice, Corn (binthe) is one of the world's most important food crops. Corn kernels are a potential source of carbohydrates for comestibles and noncomestible [3].

According to Sulistyowati (1999) ${ }^{4}$, four varieties of corn are often cultivated in Indonesia:

a. Zea mays underata sturt (jagung gigi kuda) that is often attacked by Sitophilus zeamais Motschulsky (greater grain weevil).

b. Zea mays indurate sturt (jagung mutiara) that is resistant to pests.

c. Zea mays sacharata sturt (sweet corn)

d. Zea mays everata sturt that is used for pop corn

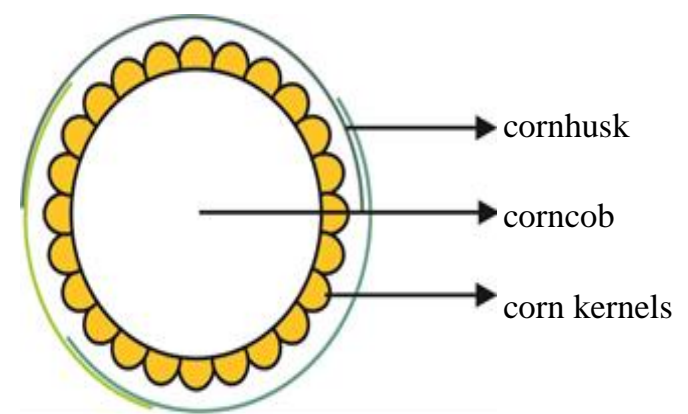

Fig. 1. The anatomy of corn

Source: Hasdiana, $2015^{5}$ 
Sulistyowati $(2004: 2)^{6}$, states that Cornhusks/shuckers layer over the cobs and every layer has different thickness and flexibility. The corn crop has one or two cobs based on its variety. The cob is layered by cornhusks. Corncobs located at the top are generally first formed and larger than those located at the bottom. Each corncob consists of 10-16 rows of seeds whose numbers are not odd.

According to Wijayanti $(2011: 24)^{7}$, the ground tissue of cornhusk is parenchyma. Parenchyma is the main ground tissue contained in plant organs and forming a continuous tissue. Parenchymal tissue is a tissue composed of primary cell walls in the primary plant body. Based on the chemical content, cornhusk has $42 \%$ of cellulose. The primary function of cellulose is to maintain the structure and stiffness of the plant. Cellulose acts as a framework to enable plants to retain their strengths in different shapes and sizes. (Ginting, 2015: $53)^{8}$

\begin{tabular}{|l|l|}
\hline Substance & Husk \\
\hline Cellulose (\%) & $42.31 \pm 0.7$ \\
\hline Lignin (\%) & $12.58 \pm 0.2$ \\
\hline Ash (\%) & $4.16 \pm 0.26$ \\
\hline Others (\%) & 40.95 \\
\hline Crystallization (\%) & $34.57 \pm 0.91$ \\
\hline
\end{tabular}

Source of Data: Huda, $2008^{9}$

Bandung textile center has stated that cornhusk contains a high fiber that can be processed to be the raw material for textile products - interior design needs and clothes that become eco-friendly textile product. (http://erabaru.net/iptek/80-bumilingkungan-/18915-produktekstil-kelobot-jagung) ${ }^{10}$. Paramita $(2010)^{11}$ has stated that cornhusk can be utilized as a product so that it can add the value of the waste of cornhusk.

These opinions indicate that it is reasonable to keep exploring the processing of corn and its parts, so the corn (maize) can be optimal to be a superior product for the people of Gorontalo

\section{B. Classification of Textile Fiber}

Textile fibers as raw materials for the textile industry play a very important role. There are many various fibers - natural and synthetic fibers-used in a textile company. The characteristic of the used textile fibers will affect the processing and determine the characteristic of the finished textile material.

There are many ways to classify textile fibers, but the textile fiber is generally classified into two kinds namely

\section{1) Natural fiber.}

The fiber classified into a natural fiber is a fiber that is directly produced in nature. A natural fiber is classified into three types namely
a. Cellulose fiber
b. Protein Fiber.
c. Mineral fiber

\section{2) Synthetic Fibers}

Synthetic fiber is classified into two types namely: Artificial fibers and Synthetic fibers. The cornhusk that will be used in this research is classified into a natural fiber-a fiber that is produced in nature.

\section{The Characteristic and Tenacity of Fibers}

The physical and chemical structure greatly influences the fiber properties including tenacity, flexibility and elasticity, absorbency, resilience, and resistance to rubbing, chemicals, and others. Therefore, to improve the quality of the cornhusk needs to test the tenacity of cornhusk.

The tenacity of a fiber is defined as the ability of the fiber to retain the pull and strain expressed as the tensile strength. The unit of measurement for the tensile strength can be PSI (pound per square inch) or GPD (gram per denier). (ITT, $1977: 13)^{12}$.

Generally, the tenacity of the fibers in wet condition will decrease, but the tenacity of cellulose fibers in the wet condition will be higher than in a dry condition. Table 1 illustrates the tenacity of the textile fibers in dry and wet conditions shows whether the tenacity of cornhusk will be improved or not after having been given the treatment.

TABLE.1. THE TENACITY OF THE TEXTILE FIBERS

\begin{tabular}{|c|c|c|}
\hline \multirow{2}{*}{ KINDS OF FIBERS } & \multicolumn{2}{|c|}{ CONDITION } \\
\hline & DRY & WET \\
\hline Fortisan & 8,5 & 5,5 \\
\hline $\mathrm{R} \mathrm{a} \mathrm{m} \mathrm{i}$ & 6,7 & 8,7 \\
\hline Flax & 6,6 & 8,4 \\
\hline Glass & 6,4 & 5,6 \\
\hline Nylon & $8,8-4,3$ & $7,4-3,6$ \\
\hline Dacron & $7,5-4,5$ & $7,5-4,5$ \\
\hline Vycron & $6,3-4,2$ & $6,3-4,2$ \\
\hline Silk & 4,5 & 3,9 \\
\hline Fortrel & $4,7-3,7$ & $4,7-3,7$ \\
\hline Cotton & 3,8 & 4,8 \\
\hline \multirow{2}{*}{ KINDS OF FIBERS } & \multicolumn{2}{|c|}{ CONDITION } \\
\hline & DRY & WET \\
\hline Zeftan & 3,5 & 3,1 \\
\hline Denyl & $3,3-2,5$ & $3,3-2,5$ \\
\hline Kodel & $3,0-2,5$ & $3,0-2,5$ \\
\hline Verel & $2,8-2,5$ & $2,7-2,4$ \\
\hline Cresian & 2,7 & 2,7 \\
\hline Acrilan & $2,7-2,0$ & 2,0 \\
\hline Orlon & 2,5 & 2,5 \\
\hline Saran & 2,5 & 2,5 \\
\hline Rayon & $1,7-5,0$ & 1,0 \\
\hline Arnel & $1,2-1,4$ & $0,8-1,0$ \\
\hline Wool & 1,3 & 0,8 \\
\hline Vinyon HH & $0,7-1,0$ & $0,7-1,0$ \\
\hline
\end{tabular}

Source of Data: Knowledge of textile goods, 1977

Based on the above table, the result of the textile-fiber tenacity of the cornhusks in dry condition shows whether the tenacity of cornhusk will be improved or not after having been given the treatment. 


\section{METHODS}

This research uses an experimental method. The process of this research will pass two steps - identifying the characteristic of cornhusk by observing naturally and testing the chemical structure of the cornhusk including the tenacity of the cornhusk after being given the treatment by soaking it into $\mathrm{CH}_{3} \mathrm{COOH}$ and processing the cornhusk namely coloring, sorting, weaving, and forming.

The required data will be collected by using mthode of observation, literature study, and documentation. The taking of the material is done by taking the corn husk in wet condition randomly from the corn seller in a Central Market of Gorontalo.

\section{RESULT AND DISCUSSION}

The cornhusk that is used in this research is the husk of sweet corn. The reason is the size of the husk of sweet corn is wider than the husk of other corns and in Gorontalo, the husks of sweet corn are easier to get than others are.

Data obtained from Gorontalo Corn Information Center and Food Security Agency (BKPPIJ)
a. Boni'a corn (Jagung Boni'a)
b. Momala corn (Jagung Momala)
c. Motoro Kiki corn (Jagung Motoro Kiki)
d. Pulut local corn (Jagung Pulut lokal)

Of the four types of local corn, only Motoro Kiki and Local Pulut corn are found. Motoro kiki (Binthe Kiki) corn is a local variety of Gorontalo corn that has been registered as a local superior corn of Gorontalo that has a legal recognition of rights and ownership of varieties according to Law PVT Number 29 year 2000.

Generally, the variety of Motoro Kiki Corn seeds are consumed in dried form. The researcher has little difficulty to get fresh cornhusk from this variety, since the peeling of the husk is done first before the corn is sold and the cornhusk is directly utilized as an animal feed.

Many people still consume Local Pulut corn, but it is the same as Motoro Kiki Corn. The researcher has little difficulty to get fresh cornhusk from this variety, since the variety of MotoLocal Pulut Corn is generally consumed in dried form eventhough it has been sorted or not yet.

It is different from sweet corn; this variety is usually harvested and traded in traditional markets in the whole state completed by the husk. Although, sweet corn is actually a hybrid corn - the corn produced by cross-pollinated plant that is heterozygot and homogeny (Rena, BKPPIJ, July 25, 2016, 13:00 pm ${ }^{13}$, but the availability of sweet corn in Gorontalo is quite abundant, so automatically it is Easy to get the fresh husk in large quantities.

\section{A. Identification of the caharacteristic of cornhusk}

\section{1). Natural Observation}

Based on the results of natural observation and observation of the physical properties of cornhusk that include the number of layers of cornhusk, size, color, thickness and flexibility, the characteristics of cornhusk are shown in table 2.

It can be seen from table 2 that the arrangement of cornleaf can be divided into three, the outer layer, the middle layer and the inner layer. From several samples of cornleaves, the leaf width of cornhusk is about 22-10 centimeters and the length of cornhusk is about 25-18 centimeters with dark green, pale green and white.

The outerlayer of cornhusk is generally dirty and hard fibrous, so it is easily broken and cannot be used as a material for making millineris. It is different from inner layer of cornhusk, although the inner layer of cornhusk is flexible enough but it is fragile. If it is used as material in the manufacture of applicable textile craft products, it will be easily damaged more quickly in a short time.

In this research, the middle layer of the cornhusk is choosen as the middle layer is clean, medium-sized, pale-

TABLE.2. THE CHARACTERISTIC OF CORNHUSK

\begin{tabular}{|c|c|c|c|c|}
\hline No & $\begin{array}{c}\text { Physical } \\
\text { characteristic }\end{array}$ & Outer layer & $\begin{array}{c}\text { Middle } \\
\text { layer }\end{array}$ & Inner layer \\
\hline 1 & $\begin{array}{c}\text { Layer of } \\
\text { cornhusk }\end{array}$ & $\begin{array}{c}3 \text { Outer } \\
\text { Layers }\end{array}$ & $\begin{array}{c}\text { Middle } \\
\text { Layer }\end{array}$ & $\begin{array}{c}3 \text { Inner } \\
\text { Layers }\end{array}$ \\
\hline 2 & Width & $\pm 22 \mathrm{~cm}$ & $\pm 18 \mathrm{~cm}$ & $\pm 10 \mathrm{~cm}$ \\
\hline 3 & Length & $\pm 25 \mathrm{~cm}$ & $\pm 23 \mathrm{~cm}$ & $\pm 18 \mathrm{~cm}$ \\
\hline 4 & Color & Dark green & Pale green & White \\
\hline 5 & Thickness & $\begin{array}{c}\text { Thick/ } \\
\text { Hard }\end{array}$ & $\begin{array}{c}\text { Rather } \\
\text { Thick }\end{array}$ & Thin/Soft \\
\hline 6 & Flexibility & Not flexible & Flexible & Flexible \\
\hline
\end{tabular}

green or white and eventhough it is slightly thicker but the texture is more flexible. Then experimentation on the processing of cornhusk and application on textile products is conducted.

The result of observation on the characteristics of cornhusk shows that it is potential and prospect as the basic material of textile product manufacture because of its high fiber content, besides the abundant supply of cornhusk in Gorontalo

\section{2). Chemical Structure Testing}

The testing of the chemical structure of cornhusk is focused on Test of cornhusk (calibration) strength. This test is necessary to know the quality of raw materials before being processed and traded.

The type of the cornhusk test is test of bundle tensile strength with reference to SNI ISO 08-1112-89, using formula:

$\begin{aligned} & \text { Tenacity } \\ & (\mathrm{g} / \mathrm{Tex})\end{aligned}=\frac{\text { Bundle strength }(\mathrm{kg}) \quad \mathrm{X} 50}{\text { Weight in length } 5 \mathrm{~cm}(\mathrm{mg})}$ 
The results of 10 samples of $1 \mathrm{~cm}$ wide and 18-20 $\mathrm{cm}$ long, which has been immersed for 45 minutes and 12 hours by using $\mathrm{CH}_{3} \mathrm{COOH}$ and without immersion, the result is:

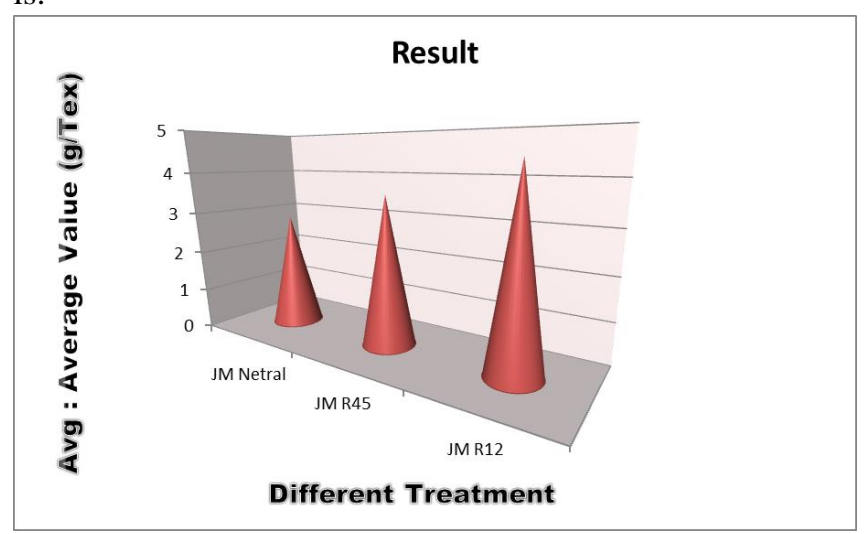

Fig. 2. Results of cornhusk immersion using $\mathrm{CH}_{3} \mathrm{COOH}$

In Figure 2, it has been described that cornhusk soaked with ordinary water has strength of $2.86 \mathrm{~g} / \mathrm{t}$ Tex and the color is still green, while cornhusk soaked with $\mathrm{CH}_{3} \mathrm{COOH}$ for 45 minutes will increase the strength to $3.58 \mathrm{~g} /$ Tex with a bit brighter color. If it is compared with Cornhusk soaked with $\mathrm{CH}_{3} \mathrm{COOH}$ for 12 hours, the strength of cornhusk will be more improved to be $4.4 \mathrm{~g} / \mathrm{Tex}$ and the color is pale light. From the results of these experiments, it can be concluded that soaking the cornhusk with $\mathrm{CH}_{3} \mathrm{COOH}$ will be able to improve the strength of the cornhusk and will automatically improve the quality of cornhusk as raw material for textile products.

\section{B. The processing of cornhusk}

\section{1) Sorting, Bleaching, coloring}

After identification of the types of cornhusk, it will be continued to explore the technique of preservation of cornhusk. Processing begins with bleaching stage with chemicals also known as bleachingprocess and genrally the color of cornhusk will be greenish or pale green.

Bleaching process can be done by soaking with chemicals Acetic acid, ethanoic acid or vinegar that has a chemical formula $\mathrm{CH}_{3} \mathrm{COOH}$. It is an organic acid chemical compound known as acid flavor and aroma in food. The length of immersion depends on the thickness of the media to be bleached. Immersion can be done between 45 minutes to 12 hours.

After the bleaching process, it is continued to the process of dyeing cornhusk by boiling water, then give the desired dye (dye base or dye direct or napthol) and mix well. Put the cornhusk, the longer the cooking process the darker the color will be got. After the color matches with the desired color then lift and drain the corn leaves. The process of drying can be done by drying in the sun to dry half and then it can be aerated or aerated to dry. The last, the cornhusk is ironed in the warm temperature.

\section{2) Weaving}

This tested weave uses a simple loom or non-machine loom (ATBM) with a woven base weaving structure that is cross between two threads that are intertwined perpendicular to each other.

Type of woven is the same as the type of woven in general; these threads are divided into two directions, namely the vertical direction called warp thread and horizontal direction called threads. Only in the woven fabric made in this study, weftyarn filled with cornhusk material that has been processed before by bleaching process, the coloring process and then the husk of the corn is cut into size $1 \mathrm{~cm}$ then woven.

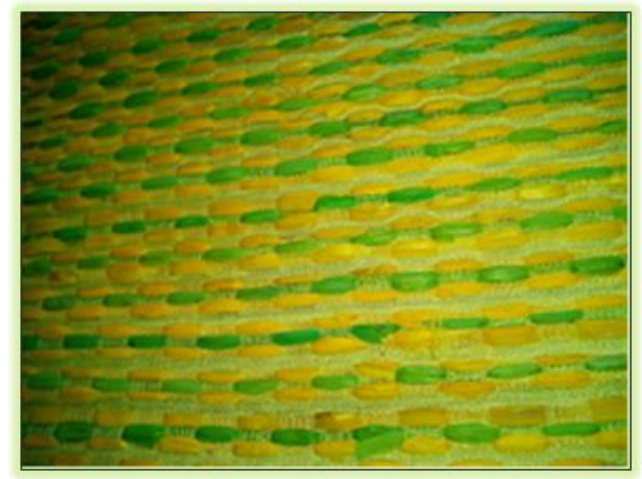

Fig. 3. The result of cornhusk woven

\section{3) Forming}

After the exploration of corn husk as the raw material is done, then it is the time to realize the work of bags from cornhusk that is woven.

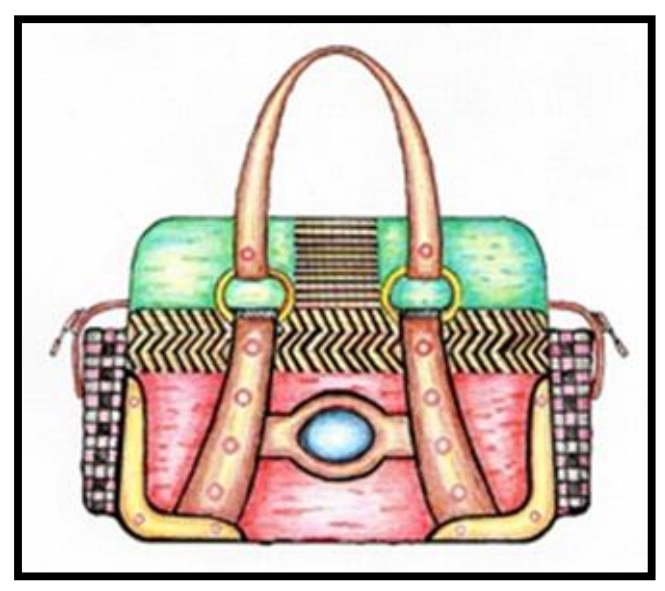

Fig. 4. Design of bag from cornhusk.

Idea sources are predetermined, it is followed by the determination of materials and tools in accordance with the representations of existing sketches. After the materials and tools that will be used is available and then it is followed by the stape of pattern makin in accordance with the design of the bag. 


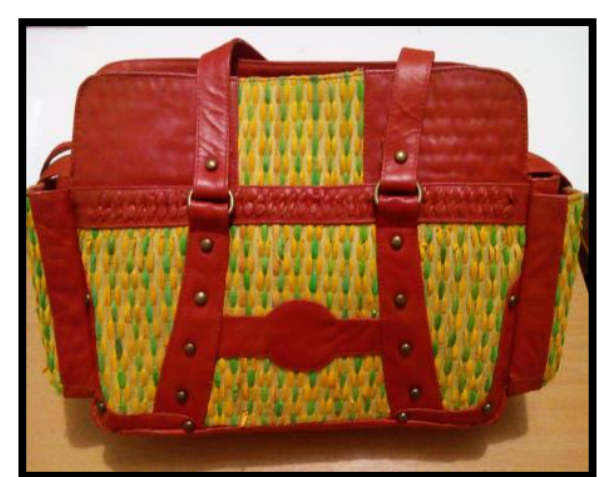

Fig. 5. The result of bag from cornhusk

\section{CONCLUSION}

Based on the results of research and discussion it can be concluded that optimal maize cultivation will provide broader benefits such as economic, tourism, arts, and culture improvement, which will ultimately improve the welfare of the community and increase the regional income. When it is made with a creative touch, cornhusk can provide the added value. For the first time it was just a waste that is not valuable. it will turn into functional objects, aesthetic, and even and it can be a mascot for Gorontalo region as a pioneer in the corn processing.

\section{ACKNOWLEDGMENT}

Thanks to:

\section{- DRPM Kemristekdikti}

- LPPM State University of Gorontalo.

\section{REFERENCES}

[1] Ginting, Artarita. (2015) Pemanfaatan Limbah Kulit Jagung untuk Produk Modular dengan Teknik Pilin. Dinamika Kerajinan dan Batik, No. 570/Akred/P2MI-LIPI/04/2014 pp. 51-62.

[2] Baruadi, Mahludin, H. (2013) Kaji Ulang Program Agropolitan Provinsi Gorontalo. Research report Retrived Repository.ung.ac.id Januari 2016

[3] Rukmana, Rahmat. (2012). Usaha Tani Jagung. Kanisius. Yogyakarta.

[4] Sulistyowati, Retno dan Koesmaningsih, Ratna, (1999) Berkreasi dengan Kulit Jagung. Puspa Swara, Jakarta.

[5] Hasdiana. (2015). Inovasi Limbah Kulit Jagung Menjadi Bahan Baku Produk Tekstil. Proceeding National Conference Bosaris VII. University Press. Pp.64-71.

[6] Sulistyowati, Retno dan Koesmaningsih, Ratna, (1999) Berkreasi dengan Kulit Jagung. Puspa Swara, Jakarta. unpublished

[7] Wijayanti, Septi, Enggar, (2011) Pengaruh Penambahan Volume Air Terhadap Hasil Pewarnaan Kulit Jagung dengan Zat Warna Direct. PKK FT Unesa. Surabaya.

[8] Ginting, Artarita. (2014) Pemanfaatan Limbah Kulit Jagung untuk Produk Modular dengan Teknik Pilin. Dinamika Kerajinan dan Batik, No. 570/Akred/P2MI-LIPI/04/2014 pp. 51-62

[9] Huda, S.N, Compotition From Chiken Feather and CornhuskPreparation and Characterization, (University of Nebrasca, Nebrasca, 2008)

[10] Era Baru News, (2010), Tekstil Kulit Jagung Ramah Lingkungan. Era Baru News (online) vol, No. http://erabaru.net/iptek/80-bumilingkungan/18915-produk-tekstil-dari-kelobot-jagung, diakses 20 November 2011.

[11] Paramita, N. (2010) Eksplorasi Olah Serat Jagung (Zea Mays) Melalui Proses Teknik Non Tenun Unruk Alternatif Produk-peoduk Kria. Skripsi. Institut Teknologi Bandung.

[12] Institut Teknologi Tekstil. (1977). Pengetahuan Barang Tekstil. Bandung.

[13] Rena. BKPPIJ, Interview on Juli 25, 2016, 13.00pm. 